\title{
PENGARUH PRODUK, HARGA, DISTRIBUSI DAN PROMOSI TERHADAP KEPUTUSAN PEMBELIAN KONSUMEN DI MINIMARKET RADJA PAS RANTAUPRAPAT KABUPATEN LABUHANBATU
}

\author{
Lestari $^{1}$, Daslan Simanjuntak ${ }^{2}$ \\ ${ }^{1}$ Alumni STIE Labuhanbatu \\ Dosen STIE Labuhanbatu
}

\begin{abstract}
ABSTRAK
Saat ini keberadaan tempat perbelanjaan yang lengkap, aman, nyaman, bersih tidak hanya di kota-kota besar saja tetapi sudah menyebar ke semua daerah. Minimarket Radja Pas Rantauprapat Kabupaten Labuhanbatu merupakan salah satu bentuk bertahannya Minimarket ditengah-tengah persaingan bisnis yang semakin ketat. Semakin bertambah banyaknya toko yang menyediakan kebutuhan sehari-hari masyarakat, membuat Minimarket Radja Pas Rantauprapat Kabupaten Labuhanbatu harus mampu bersaing secara ketat dan profesional. Keberadaan Minimarket Radja Pas Rantauprapat Kabupaten Labuhanbatu merupakan suatu bentuk dari keinginan konsumen yang ingin berbelanja berbagai kebutuhan sehari-hari secara efisien di satu tempat karena dapat menghemat waktu dan biaya. Dari Hasi penelitian yang berjudul "Pengaruh Produk, Harga, Distribusi dan Promosi Terhadap Keputusan Pembelian Konsumen Di Minimarket Radja Pas Rantauprapat Kabupaten Labuhanbatu” dengan jumlah kurang lebih 150 populasi dan 60 sampel. Hasil uji t (parsial) yang di dapat yaitu Variabel Produk $\left(X_{1}\right)$ berpengaruh positif tetapi tidak signifikan terhadap keputusan pembelian konsumen dimana 1,922 > 1,67 dengan probabilitas 0,060>0,05. Variabel Harga $\left(X_{2}\right)$ berpengaruh positif dan signifikan terhadap keputusan pembelian konsumen dimana 3,799 > 1,6 dengan probabilitas 0,000 < 0,05 . Variabel Distribusi $\left(X_{3}\right)$ berpengaruh positif tetapi signifikan terhadap keputusan pembelian konsumen dimana 1,752 > 1,67 dengan probabilitas 0,085 > 0,05. Variabel Promosi $\left(X_{4}\right)$ berpengaruh positif tetapi tidak signifikan terhadap keputusan pembelian dimana 0,290 < 1,67 dengan probabilitas 0,773 $>0,05$. Hasi uji $f$ (simultan) variabel produk $\left(X_{1}\right)$, harga $\left(X_{2}\right)$, distribusi $\left(X_{3}\right)$, promosi $\left(X_{4}\right)$, secara bersama-sama berpengaruh terhadappeningkatan keputusan pembelian konsumen $(Y)$. Hal ini dapat dilihat dari $f_{\text {hitung }}>f_{\text {tabel }}=23,495>4,02$ dengan probabilitas $0,000<0,05$. Dan variabel produk $\left(X_{1}\right)$, harga $\left(X_{2}\right)$,distribusi $\left(X_{3}\right)$, promosi $\left(X_{4}\right)$ mampu mempengaruhi keputusan pembelian konsumen $(Y)$ sebesar $63,1 \%$.
\end{abstract}

Kata kunci : Produk, Harga, Distribusi, Promosi terhadap Keputusan Pembelian Konsumen. 


\section{PENDAHULUAN}

Perubahan kondisi ekonomi dan sosial yang dinamis telah dengan cepat merubah prilaku dan sikap konsumen. Dengan susunan pilihan produk yang memusingkan yang ada di pasar.Konsumen sudah pasti menempatkan posisi tertinggi mengharapkan sesuatu yang lebih dari sebelumnya Mereka tidak hanya mengharapkan suatu produk yang berkualitas tinggi karena kualitas produksudah merupakan suatu norma dan persyaratan.

Perkembangan zaman saat ini menuntut konsumen bersikap pintar, cermat, efisien, dan efektif dalam memilih produk yang di inginkan. Dengan adanya sikap itu, maka konsumen tidak akan kecewa dengan apa yang mereka beli (action). Dalam kehidupan sehari-hari konsumen dihadapi dengan berbagai kebutuhan yang tiada henti, karena memang pada dasarnya manusia tidak lepas dari kebutuhan dan tidak akan terpuaskan dari kebutuhan mereka.Mulai dari produk yang bersifat kecil kebutuhannya sampai yang bersifatbesar. Denganmeningkatkankeberhasilan perusahaan dalam pemasaran akan membuat konsumen untuk berbelanja di perusahaan tersebut. Memberikan tipe kepribadian yang dapat di klasifikasi dan korelasi yang kuat terdapat antara jenis kepribadian tertentu dan pilihan produk atau merek.Saat ini keberadaan tempat perbelanjaan yang lengkap, aman, nyaman, bersih tidak hanya di kota-kota besar saja tetapi sudah menyebar ke semua daerah. Minimarket Radja Pas Rantauprapat Kabupaten Labuhanbatu merupakan salah satu bentuk bertahannya Minimarket ditengahtengah persaingan bisnis yang semakin ketat. Semakin bertambah banyaknya toko yang menyediakan kebutuhan sehari-hari masyarakat, membuat Minimarket RadjaPas Rantauprapat Kabupaten Labuhanbatu harus mampu bersaing secara ketat dan profesional.KeberadaanMinimarketRadjaPas Rantauprapat Kabupaten Labuhanbatu merupakan suatu bentuk dari keinginan konsumen yang ingin berbelanja berbagai kebutuhan sehari-hari secara efisien di satu tempat karena dapatmenghemat waktu dan biaya. Konsumen ingin berbelanja di tempat yang bersih, praktis dan mampu menyediakan kebutuhan sehari-hari konsumennya. Apalagi jika konsumen tidak ingin jauh-jauh ke daerah kota untuk berbelanja karena menghabiskan banyak waktu.Minimarket Radja Pas Rantauprapat Kabupaten Labuhanbatuberusaha mewujudkan keinginan konsumennya dengan menjual berbagai alat kebutuhan seharihari seperti : alat tulis, kosmetik, makanan hingga peralatan dapur. Namun di tengah persaingan usaha yang semakin ketat membuat Minimarket Radja Pas Rantauprapat KabupatenLabuhanbatu harus meningkatkan kembali jenis dan jumlah produk yang di jual, harga yang mampu bersaing dengan Minimarket ataupun toko-toko lainnya,Pendistribusian yang dilakukan Minimarket Radja Pas juga sangat memperhatikan kebutuhan sesuai jenis produk yang di jual. Lokasi yang mampu memberikan rasa aman dan kenyamanan bagi konsumennya ketika berbelanja. Dan meningkatkan kegiatan promosi melalui media cetak maupun elektronik seperti : Radio serta memberikan promo-promo menarik ataupun diskon kepada para konsumennya.

Dari penelitian langsung ke lapangan, produk yang dijual di Minimarket Radja Pas Rantauprapat cukup beraneka ragam dan menjual kebutuhan sehari-hari konsumen. 
Namun, Minimarket Radja Pas Rantauprapat tidak menjual bahan-bahan masakan yang cepat busuk dan tidak bertahan lama seperti : sayur-sayuran, ikan dan lain sebagainya.

Harga yang ditawarkan juga cukup beraneka ragam walaupun beberapa masih terdapat produk yang tinggi harganya seperti barang pecah belah, pakaian dan lain-lain.Lokasi Minimarket Radja Pas sebenarnya terbilang kurang strategis karena lokasinya yang berada jauh ke dalam sehingga konsumen merasa sedikitkesulitan untuk menemukannya. Sehingga dibutuhkan media promosi seperti radio agar konsumen mengetahui dengan pasti lokasi dari Minimarket Radja Pas.

Keputusan pembelian konsumen terjadi apabila produk, harga, distribusi maupun promosi mampu menarik perhatian konsumen. Maka untuk menarik konsumen Minimarket Radja Pas Rantauprapat harus mampu mewujudkan keinginan konsumennya.

Berdasarkan latar belakang yang di uraikan maka untuk mengetahui bagaimana hubungan antara pengaruh produk, harga, lokasi, promosi dan keputusan pembelian konsumen, penulis melakukan penelitian dengan judul: "Pengaruh Produk, Harga, Distribusi dan Promosi Terhadap Keputusan Pembelian Konsumen Di Minimarket Radja Pas Rantauprapat Kabupaten Labuhanbatu”.

\section{TINJAUAN PUSTAKA Bauran Pemasaran}

Bauran pemasaran merupakan salah satu elemen dalam strategi pemasaran jasa maupun produk. Buran pemasaran mempunyai peranan yangsangat penting dalam kemajuan perusahaan sehingga bauran pemasaranharus dilakukan dengan penuh pertimbangan yang tepat. Bauran pemasaran juga merupakan seperangkat alat yang dapat di gunakan pemasar untuk membentuk karakteristik jasa yang di tawarkan kepada pelanggan.

\section{Pengertian Produk}

Produk adalah keseluruhan konsep objek atau proses yang memberikan sejumlah nilai manfaat kepada konsumen. Yang perlu diperhatikan dalam produk adalah konsumen tidak hanya membeli fisik dari produk itu saja tetapi juga membeli manfaat dan hasil dari produk tersebut.Menurut Tjiptono (2008) Produk merupakan segala sesuatu yang dapat ditawarkan produsen untuk diperhatikan, diminta, dicari, dibeli, digunakan, atau dikonsumsi pasar sebagai pemenuhan kebutuhan atau keinginan pasar yang bersangkutan.

\subsubsection{Tingkatan Level Produk.}

Dalam merencanakan penawaran atau produk, pemasar perlu memahami lima tingkatan produk yaitu:produk utama/ inti (core benefit), yang menawarkan manfaat atau kegunaan utama yang dibutuhkan pelanggan.Produk generik, yang mencerminkan versi dasar (fungsional) dari suatu produk.Produk yang diharapkan (expectedproduct), yaitu sekumpulan atributdan kondisi yang biasa diharapkan pelanggan pada saat melihatnya.Produktambaha(augmentedproduct), meliputipelayanandanmanfaatyangmem bedakanpenawaran perusahaan dengan penawaran perusahaan pesaing.

Produk potensial, yaitu segala tambahan dan transformasi pada produk yang mungkin dilakukan dimasa mendatang. 


\section{Pengertian Place (Distribusi)}

Pengertian distribusi dapat diartikan sebagai kegiatan pemasaran yang berusaha memperlancar danmempermudah penyampaian barang dan jasa dari produsen ke konsumen sehingga penggunaannya sesuai yang diperlukan (Tjiptono, 2008).Dalam pelaksanaan distribusi ada 3 alternatif yang dapat digunakan, yaituDistribusi langsungDistribusi tidak langsungKombinasi antara distribusi langsung dan distribusi tidak langsungMenurat Tjiptono (2008), Saluran distribusi dibutuhkan terutama karena kesenjangan diantara produksi dan konsumsi kesenjangan (Gap) tersebut adalah :

Geographical gab, yaitu kesenjanganyang terjadi disebabkan oleh tempat pemusatan produksi dan lokasi yang tersebar dimana mana.Time Gap, kesenjangan yang terjadikarena adanya kenyataan bahwa pembelian atau konsumsi dilakukan hanya pada waktu waktu tertentu sementara produksi (agar efisien) berlangsung terus menerus sepanjang waktu.Quantity Gap, yaitu gap dalamjumlah dimana jumlah barang yang diproduksi secara otomatis oleh produsen berbeda dengan kuantitas normal yang diinginkan konsumen.Assortment Gap, dimana produsenumumnya secara spesialisasi padaproduk tertentu, sedangkan konsumen menginginkan produk yang beraneka ragam.

Communication and information gap,yaitu kesenjangan yang timbul karena konsumen tidak tahu menahu dimana sumber-sumber produksi yang menghasilkan produk yang diinginkan atau dibutuhkannya, sementara dilain pihak produsen tidak tahu siapa dan dimana pembeli potensial berada.

\subsubsection{Cara mengatasi masalah Distribusi}

Menurut McCarthy dan Perreault dalam Tjiptono (2008), Untuk mengatasi masalahmasalah memerlukan berbagai penyesuaian yang meliputi tugas pokok sebagai berikut: 1) Accumulating adalah aktifitasmengumpulkan barang-barang dari berbagai produsen. Bulk breaking merupakan aktifitasmembagi produk berbagai produsen itu masing-masing kedalam kuantitas yang lebih kecil, sesuai dengan yang dibutuhkan atau diminta konsumenSorting adalah aktifitas yanghomogen dengan spesifikasi dan tingkattingkat tertentu.

Assorting adalah menjual berbagaimacam lini produk ini tergantung pada besar kecilnya bisnis perantara. Semakin besar bisnis perantara semakin besar pula jumlah lini produk, jumlah variasi produk atau merk pada masing-masing liniproduk berdasarkan kegunaannya.

\subsubsection{Kriteria memilih saluran distribusi.}

Menurut Tjiptono (2008), Untuk memilih saluran distribusi perusahaan harus mengikuti pertimbangan - pertimbangan sebagai berikut:Pertimbangan pasarPertimbangan produkPertimbangan perantaraPertimbangan perusahaan 


\section{Pengertian Promotion (Promosi)}

Promosi adalah arus informasi atau persuasi satu arah yang dibuat untuk mengarahkan seseorang atau organisasi kepada tindakan yang menciptakan pertukaran dalam pemasaran (Sukotjo, 2010).

Menurut Merurut Tjiptono (2008), Strategi promosi meliputi hal sebagai berikut:

Strategi Pengeluaran Promosi.Strategi Pemilihan Media.

Dalam pemilihan media harus memperhatikan alternative pemilihan media adalah sebagai berikut ini:Media CetakMedia ElektronikMedia Luar RuangMedia Lini BawahStrategi Copy PeriklananStrategi Penjualan.Strategi motivasi dan penyelia tenaga penjual.

\section{Keputusan Pembelian Konsumen}

Menurut Kotler (2007) keputusanpembelian adalah tahap dalam proses pengambilan keputusan pembeli dimana konsumen benar-benar akan membeli.

Proses keputusan pembelian melibatkan bermacam-macam faktor yang mempengaruhi pembeli. Lima peran yang dimainkan orang dalam keputusan pembelian (Kotler, 2007) adalah sebagai berikut :

a) Pencetus (initiator) adalah seseorang yan pertama kalimengusulkan gagasan untuk membeli suatu produk atau jasa.

b) Pemberi pengaruh (influencer) adalah seseorang yang pandanganatau sarannya mempengaruhi keputusan.

Pengambil keputusan (decider) adalah seseorang yang mengambil keputusan untuk setiap komponenkeputusanpembelian,apakahmembeli, tidak membeli, bagaimana membeli dan dimana akan membeli.Pembeli (buyer) adalah orang yangmelakukan pembelian yang sesungguhnya.Pemakai (user) adalah seseorangyang mengkonsumsi atau menggunakan produk atau jasa yang bersangkutan.

\section{Faktor-faktor yang mempengaruhi keputusan konsumen}

Dalam memahamiperilakukonsumen perlu dipahami siapa konsumen, sebab dalam suatu lingkungan yang berbeda akan memiliki penelitian, kebutuhan, pendapat, sikap dan selera yang berbeda.

Menurut Kotler (2007) : faktor-faktor yang mempengaruhi perilaku konsumen :Faktor kebudayaanFaktor kebudayaan memberikanpengaruh paling luas dan dalam pada tingkah laku konsumen pemasar harus mengetahui peran yang dimainkan oleh :BudayaSub budayaKelas sosialFaktor sosialTingkah laku konsumen juga di pengaruhi oleh faktor-faktor sosial, yaitu :KelompokKeluargaPeran dan statusFaktor pribadiKeputusan membeli juga di

pengaruhi oleha karakteristik pribadi, yaitu :Umur dan tahap daur hidupPekerjaan.Situasi ekonomi.Gaya hidupKepribadian dan konsep diriFaktor psikologis.Pilihan barang yang dibeli seseorang lebih lanjut dipengaruhi oleh faktor psikologi yang penting, yaitu :Motivasi.

PersepsiPengetahuanKeyakinan dan sikap 


\section{METODE PENELITIAN Populasi}

Populasi dalam penelitian ini adalah jumlah Masyarakat yang datang ke Minimarket Radja Pas Rantauprapat Kabupaten Labuhanbatu perhari rata-rata sebanyak 150 orang yang berbelanja di Minimarket Radja Pas Rantauprapat Kabupaten Labuhanbatu. Dan jumlah sampel dalam penelitian ini adalah 60 orang.

\section{Jenis Dan Sumber Data}

Adapun jenis data yang dibutuhkan dalam penelitian ini adalah : a) Data primer yaitu data yangdiperoleh dengan cara observasi langsung berupa pengamatan dan wawancara dengan bagian penjualan dan bagian Data yang diperoleh berupa informasi tertulis serta dokumentasi dan laporan tentang keadaan perusahaan yang meliputisejarah ringkas berdirinya perusahaan, atau dokumen lain yang relevan dengan judul skripsi.Data Sekunder yaitu data yang diperoleh berupa informasi tertulis serta dokumentasi dan laporan tentang keadaan perusahaan yang meliputi sejarah ringkas berdirinya perusahaan, atau dokumen lain yang relevan dengan judul skripsi dengan mempelajari berbagai tulisan dari buku-buku, jurnal maupun internet.

\section{Analisis Data Analisis Regresi Berganda}

Penulis menggunakan Analisis regresi linier berganda untuk mengetahui pengaruh dari variable bebas produk $\left(\mathrm{X}_{1}\right)$, harga $\left(\mathrm{X}_{2}\right)$, distribusi $\left(\mathrm{X}_{3}\right)$, promosi $\left(\mathrm{X}_{4}\right)$ terhadap variabel terikat yaitu keputusan pembelian konsumen $(\mathrm{Y})$. Adapun rumus analisis regresi berganda yaitu :

$Y=1,761+0,210 X_{1}+0,421 X_{2}+0,212 X_{3}+0,030 X_{4}+e$

\section{Uji Simultan (Uji f)}

Dari hasil pengolahan data menggunakan SPSS versi 20 makadiperoleh nilai $\mathrm{f}_{\text {hitung }}$ sebesar 23,495 dengan probabilitas 0,000. Sedangkannilai $f_{\text {tabel }}$ adalah 4,02. Dengan demikian berdasarkan hasil analisis data tersebutdiketahui $f_{\text {hitung }}>f_{\text {tabel }}=23,495>4,02$ dengan probabilitas $0,000<0,05$. Hal iniberarti bahwa variabel produk $\left(\mathrm{X}_{1}\right)$, harga $\left(\mathrm{X}_{2}\right)$, distribusi $\left(\mathrm{X}_{3}\right)$, promosi $\left(\mathrm{X}_{4}\right)$, secara bersama-sama berpengaruh terhadappeningkatan keputusan pembelian konsumen (Y).

\section{Uji Parsial (Uji t)}

Digunakan untuk menguji tingkat signifikasi variabel X terhadap Y secara parsial. Sampel yang digunakan sebanyak60 orang, sehingga pengujian menggunakan uji $\mathrm{t}$ dengan $\mathrm{df}=55$ dan tingkat signifikasi $(\alpha)=5 \%=0,05$ maka diperoleh tabel sebesar 1,67.hasil pengolahan data menggunakan SPSS versi 20 maka diperoleh nilai hasil uji t dari tiap variabel $\mathrm{X}$ sebagai berikut :

Produk $\left(\mathrm{X}_{1}\right) \mathrm{t}_{\text {hitung }}=1,922$ dimana 1,922 > 1,67 dengan signifikasi 0,060 $>0,05$ maka variabel produk berpengaruh positif tetapi tidaksignifikan terhadap keputusan pembelian konsumen. 
Harga $\left(\mathrm{X}_{2}\right) \mathrm{t}_{\text {hitung }}=3,799$ dimana 3,799 > 1,67 dengan signifikasi $0,000<0,05$ maka variabel harga berpengaruh positif dan signifikanterhadap keputusan pembelian konsumen.

Distribusi $\left(\mathrm{X}_{3}\right) t_{\text {hitung }}=1,752$ dimana 1,752 > 1,67 dengan signifikasi 0,085 > 0,05 maka variabel distibusi berpengaruh positif tetapi tidaksignifikan terhadap keputusan pembelian konsumen.Promosi $\left(\mathrm{X}_{4}\right) \mathrm{t}_{\text {hitung }}=0,290$ dimana $0,290<1,67$ dengan signifikasi $0,773>0,05$ maka variabel promosi berpengaruh positif tetapi tidaksignifikan terhadap keputusan pembelian konsumen.

\section{Koefisien Determinasi $\left(\mathbf{R}^{2}\right)$}

Koefisien determinasi $\left(\mathrm{R}^{2}\right)$ digunakan untuk melihat seberapa besar variabel variabel produk $\left(\mathrm{X}_{1}\right)$, harga $\left(\mathrm{X}_{2}\right)$, distribusi $\left(\mathrm{X}_{3}\right)$, promosi $\left(\mathrm{X}_{4}\right)$, mempengaruhi keputusan pembelian konsumen (Y).

Dari hasil pengolahan SPSS, diperoleh nilai koefisien determinasi $\left(\mathrm{R}^{2}\right) 0,631$. Artinya bahwa variabel produk $\left(\mathrm{X}_{1}\right)$, harga $\left(\mathrm{X}_{2}\right)$, distribusi $\left(\mathrm{X}_{3}\right)$, promosi $\left(\mathrm{X}_{4}\right)$, mampu mempengaruhi keputusan pembelian konsumen $(\mathrm{Y})$ sebesar $63,1 \%$. Sedangkan sisanya sebesar 36,9\% dipengaruhi variabel lain yang tidak di bahas dalam penelitian ini.

\section{PEMBAHASAN}

Minimarket Radja Pas Rantauprapat Kabupaten Labuhanbatu merupakan salah satu tempat berbelanja yang menyediakan berbagai macam kebutuhan konsumen. Mulai dari alat kosmetik, barang pecah belah, berbagaimacam alat tulis, pakaian hingga makanan.Hasi ujit(parsial) di katakanberpengaruh apabila $t_{\text {hitung }}>$ dari $t_{\text {tabel }}$. Hasil $t_{\text {tabel }}$ yang di dapat adalah sebesar 1,67. Dan dalam penelitian ini hasil uji t(parsial) menunjukkan bahwa :Produk $\left(\mathrm{X}_{1}\right) \mathrm{t}_{\text {hitung }}=1,922$ dimana 1,922 > 1,67 dengan signifikasi 0,0600,05 maka variabel produk berpengaruh positif tetapi tidaksignifikan terhadap keputusan pembelian konsumen.

Harga $\left(\mathrm{X}_{2}\right) \mathrm{t}_{\text {hitung }}=3,799$ dimana 3,799 $>1,67$ dengan signifikasi $0,000<0,05$ maka variabel harga berpengaruh positif dan signifikanterhadap keputusan pembelian konsumen.

Distribusi $\left(\mathrm{X}_{3}\right) \mathrm{t}_{\text {hitung }}=1,752$ dimana $1,752>1,67$ dengan signifikasi 0,0850,05 maka variabel distribusi berpengaruh positif tetapi tidaksignifikan terhadap keputusan pembelian konsumen.Promosi $\left(\mathrm{X}_{4}\right) \mathrm{t}_{\text {hitung }}=0,290$ dimana $0,290<1,67$ dengan signifikasi 0,7730,05 maka variabel promosi berpengaruh positif tetapi tidaksignifikan terhadap keputusan pembelian konsumen.Hasi uji f (simultan) di katakanberpengaruh apabila $\mathrm{f}_{\text {hitung }}>$ dari $\mathrm{f}_{\text {tabel }}$ maka variabel $\mathrm{X}$ tersebut secara bersama-sama memiliki pengaruh yang signifikanterhadap variabel $\mathrm{Y}$. Hasil $\mathrm{f}_{\text {tabel }}$ yangdidapat adalah sebesar 4,02 bahwa variabel produk $\left(\mathrm{X}_{1}\right)$, harga $\left(\mathrm{X}_{2}\right)$, distribusi $\left(\mathrm{X}_{3}\right)$, promosi $\left(\mathrm{X}_{4}\right)$, secara bersama-sama berpengaruh terhadappeningkatan keputusan pembelian konsumen (Y). Hal ini dapat dilihat darif hitung $>$ $\mathrm{f}_{\text {tabel }}=23,495>4,02$ dengan probabilitas $0,000<0,05$. 
Hasil uji nilai koefisiendeterminasi (R2) menunjukkan bahwavariabel variabel produk $\left(\mathrm{X}_{1}\right)$, harga $\left(\mathrm{X}_{2}\right)$, distribusi $\left(\mathrm{X}_{3}\right)$, promosi $\left(\mathrm{X}_{4}\right)$ hanyamampu mempengaruhi keputusan pembelian konsumen (Y) sebesar 63,1\%. Sedangkan sisanya sebesar 36,9\% dipengaruhi variabel lain yang tidak di bahas dalam penelitian ini.

\section{KESIMPULAN}

Berdasarkan hasil penelitian ini dapat di ambil kesimpulan sebagai berikut: Secara Parsial Variabel Produk berpengaruh positif tetapi tidaksignifikan terhadap keputusan pembelian konsumen.Secara Parsial Variabel Harga berpengaruh positif dan signifikanterhadap keputusan pembelian konsumen.Secara Parsial Variabel Distribusi berpengaruh positif tetapi tidaksignifikan terhadap keputusan pembelian konsumen.Secara Parsial Variabel Promosi berpengaruh positif tetapi tidaksignifikan terhadap keputusan pembelian konsumen.Secara simultan variabel produk $\left(\mathrm{X}_{1}\right)$, harga $\left(\mathrm{X}_{2}\right)$, distribusi $\left(\mathrm{X}_{3}\right)$, promosi $\left(\mathrm{X}_{4}\right)$ secara bersama-sama berpengaruh terhadap peningkatan keputusan pembelian konsumen (Y).

\section{DAFTAR PUSTAKA}

Arikunto, Suharsimi. 2006. ManajemenPenelitian. Yogyakarta:RinekaCiptaGhozali, Imam. 2006. Aplikasi AnalisisMultivariatedenganProgramSPSS,Semarang: Penerbit Universitas Diponegoro.

Kotler, Philip. 2007. ManajemenPemasaran,Edisi Milenium.Jakarta: Salemba Empat

Kotler, Philip dan Gary Armstrong.2008.Prinsi-Prinsip

Pemasaran.Jilid 1, Edisi 8. Erlangga : Jakarta.Parasuraman

Robbins, Stephen P. (2006). Perilaku Organisasi. Edisi Sembilan.Jakarta : PT. Indeks.Sugiyono. 2007. Metode Penelitian Bisnis. Alfabeta : Bandung.

Swastha DH, Basu dan Ibnu Sukotjo W.2007.PengantarBisnisModern.Edisi 3. Liberty : Yogyakarta.

Tjiptono, Fandy. 2008. Strategi Pemasaran. Edisi 2. Andy Offset : Yogyakarta.

Zeithmal, Valeri, Parasuraman dan Bitner. 2006. Pengantar Proses Berpikir Strategik.

Jakarta : Binarupa AksaraRiyadi, Minggar. (2013). Analisis

Pengaruh Bauran Pemasaran Terhadap Keputusan Pembelian Pelumas Sepeda Motor Enduro 4t (Studi Pada Pelumas Sepeda Motor Enduro 4t Pertamina Jawa Bagian Tengah)

Pranata, Mario. (2013). Pengaruh Bauran Pemasaran Terhadap Keputusan Pembelian Di Rumah Makan Bamara Surabaya 